\title{
Botulinum Toxin in WW2 German and Allied Armies: Failures and Myths of Weaponization
}

\author{
Laurent Tatu $^{a}$ Jean-Paul Feugeas ${ }^{b}$ \\ ${ }^{a}$ Department of Neuromuscular diseases and Department of Anatomy, CHRU Besançon, University of \\ Franche-Comté, Besançon, France; 'bnteractions Hôte-Greffon-Tumeur/Ingénierie Cellulaire et Génique, INSERM, \\ Besançon, France
}

\section{Keywords}

Botulinum toxin · History of neurology $\cdot$ WW2 $\cdot$ Biological weapon

\begin{abstract}
Botulinum toxin is nowadays approved as an effective medication for various neurological disorders. The extreme toxicity of this toxin-inducing botulism, a severe lethal muscleparalyzing illness, has been well known since the seminal works of the end of the 19th century. Because of this toxicity, botulinum toxin was one of the first agents to be considered for use as a biological weapon. The Second World War was a crucial period for the first attempts to weaponize this toxin even if many unknown factors about botulinum toxin still existed at the outbreak of the war. Using documents from the British National Archives and other published sources, we discuss the main points of the attempts to weaponize this toxin in German and Allied armies. During WW2, Allied intelligence services regularly reported a major German threat related to the potential use of botulinum toxin as a biological weapon, especially during the preparation of Operation Overlord, the Allied invasion to liberate Europe. All these reports would ultimately prove to be inaccurate: botulinum toxin was not part of the German military arsenal even if some German scientists tried to use the results of the French
\end{abstract}

pre-war military research. Misinformation spread by intelligence services stimulated military research at Porton Down facilities in England and at Camp Detrick in the USA. These studies led to a succession of failures and myths about the weaponization of botulinum toxin. Nevertheless, major progress (purification, toxoid) arose from the military research, providing useful data for the first steps of the therapeutic use of botulinum toxin in the post-war years.

(c) 2021 S. Karger AG, Basel

\section{Introduction}

Botulinum toxin is nowadays approved as an effective medication for various neurological diseases, including cervical and focal dystonias, blepharospasm, or facial hemispasm. Produced by Clostridium botulinum, this toxin is responsible for botulism, a rare, but serious and lethal muscle-paralyzing illness. Food-borne botulism and wound botulism are the 2 main forms of the disease today. Because of its extreme toxicity, botulinum toxin was one of the first agents to be considered for use as a biological weapon. The Second World War was a crucial period for the first attempts to weaponize this toxin.

Many unknown factors about botulinum toxin still existed at the beginning of WW2. In 1896-1897, the Belgian karger@karger.com

www.karger.com/ene

(c) 2021 S. Karger AG, Base

Karger"
Laurent Tatu

Department of Neuromuscular diseases and Department of Anatomy

CHRU Besançon, University of Franche-Comté

3 Boulevard Fleming, FR-25000 Besançon (France)

laurent.tatu@univ-fcomte.fr 
bacteriologist Émile van Ermengen (1851-1932) discovered that botulism is caused by an anaerobic bacterium, which he named Bacillus botulinus [1]. The bacterium, renamed a few years later $C$. botulinum, releases a highly aggressive toxin whose nature was still being debated during the interwar period. By 1939, 5 serotypes (A-E) of the toxin were known, and the first methods for crude isolation of the type A toxin had been published $[2,3]$.

In 1925, the Geneva protocol prohibited the first use of chemical and biological weapons in armed conflicts but placed no constraints on research and production. At that time, botulinum toxin was not yet regarded as a potential weapon, but in the 1930 s, several countries progressively developed research on this issue.

The outbreak of WW2 was the beginning of a new period of military research on botulinum toxin, leading to a succession of failures and myths fueled by misinformation spread by intelligence services. In this article, using documents from the British National Archives and published sources, we discuss the main points of the attempts to weaponize this toxin. We focus on the German and Allied armies: the better-known experiments of Japanese Unit 731 are out of the scope of this study.

\section{A War of Misinformation}

From the pre-war period and throughout WW2, Allied intelligence services regularly indicated that Germany was attempting to develop biological weapons, in particular using botulinum toxin. The fact that Germany had initiated both chemical and biological warfare in WW1 gave credibility to this false information.

In Great Britain, in 1934, Wickham Steed (1871-1936), a British investigative journalist, published an article based on secret documents in which he claimed that Germany was involved in an active biological warfare program. Germany was said to have conducted biological experiments in the London Underground and Paris Métro [4]. We know today that no evidence of the validity of these documents was found in the German military archives: Steed was victim of a hoax [5].

At the beginning of WW2, the Allies received much erroneous information through their intelligence services. In May 1940, French intelligence services reported: "The Germans have done experiments on an isolated island off the coast of Spain infecting sheep with anthrax... An agent in Spain reported that oranges coming from Spain into France might be contaminated with bacteria... A report was received claiming that Germans had set up
3 large rat 'farms' in Czecho-Slovakia. These rats might be going to be used to some bacteriological warfare purpose." Nevertheless: "Enemy weapons are systematically examined for bacteria, but so far none have been found" [6].

In December 1943, Allen Dulles (1893-1969), head of the Office of Strategic Services (OSS) station in Bern, relayed his fear that Germany would use B. botulinus for biological warfare. The information came from Hellmuth Simons (1893-1969), a German-Jewish immigrant who worked as a microbiologist at the Zurich Polytechnic Institute. He explained that the laboratories were located at IG Farben at Hoechst and in various other facilities in Germany. Nevertheless, Dulles seemed suspicious of these statements, stating "Prof. Simons appears to have reached his conclusions through deductive evidence rather than from exact new evidence from Germany" ([7] p. 173).

Nevertheless, the rumors continued to circulate. On January 20, 1944, a letter from Philip Allen (1912-2007), a member of the British War Cabinet, stated: "A report has reached the American Chiefs of Staff from sources in Switzerland that the Germans are now in a position to use B. botulinus as a form of warfare against this country. General Eisenhower has asked that the matter should be looked into and an immediate approach was made to us since it was thought that we might have considered this particular possibility on earlier occasions" [8] (shown in Fig. 1). The preparation of Operation Overlord, the Allied invasion to liberate Europe, was the pinnacle of this misinformation war. In 1944, intelligence reports about the potential use of botulinum toxin by German troops became even more worrying. Returning from a visit to their American and Canadian colleagues in April 1944, British scientists reported their fear that "the Germans had made considerable progress in developing methods of using dry powdered X (botulinum toxin)" [9], which would have the potential to spread botulism through inhalation. We know today that all this information from Allied intelligence services would ultimately prove to be inaccurate.

\section{Not in Hitler's Arsenal}

During WW2, the real attitude of Adolf Hitler (18891945) and the German authorities towards biological warfare is now known through the reports of Alsos Mission, a secret US Army scientific unit whose primary mission was to determine Germany's nuclear weapons pro-
Tatu/Feugeas 


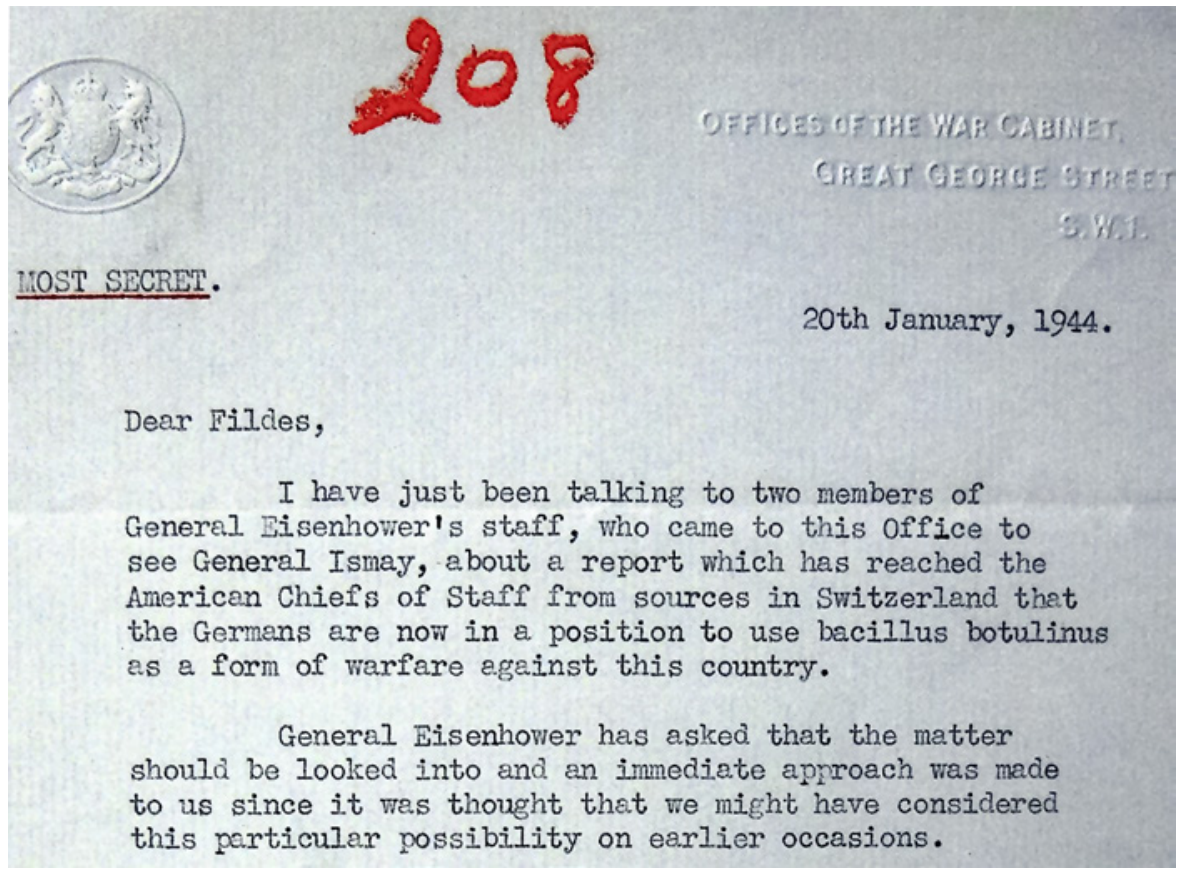

Fig. 1. Letter from Philip Allen to Paul Fildes about the German threat of Botulinum toxin use against Switzerland (British $\mathrm{Na}$ tional Archives [Kew]. WO 188/654).

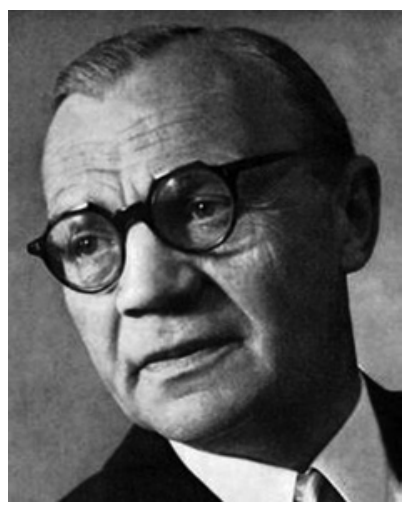

Fig. 2. Heinrich Kliewe (1892-1969) (private collection). over Germany. However, Hitler's directives clearly confirm that the work of the committee was to be confined to defensive studies. He banned all research into offensive biological warfare.

In November 1942, the Germans discovered French biological warfare documents from the pre-war period. The documents mentioned the great interest in conducting research on the combined effects of chemical and biological warfare. These data were highlighted by the committee and discussed by Marshal Wilhelm Keitel (18821946), head of the German High Command, and Adolf Hitler in March 1943. The new directives reiterated Hitler's unequivocal ban on offensive biological weapon preparations but ordered the intensive study of defensive measures against biological warfare. A new group named Blitzableiter was devoted to this policy. Kliewe's studies were then focused on aerosol generators to kill anthrax spores. He also used the captured French materials to work on the use of mustard gas (sulfur mustard) and anthrax in synergic combination.

In 1943, violating Hitler's ban, some German scientists recommended the consideration of biological weapons in sabotage: injecting botulinum toxin or typhoid into toothpaste or food. Kurt Blome (1894-1969), under cover of an anti-cancer research institute, studied offensive 
Fig. 3. Types of weaponization discussed during the French-British meeting in April 1940 (British National Archives [Kew]. WO 188/653).
$P$ ssible to $d$ s but too difficult from the manufacturing point of view. A bullet was experimented with in France of this type
Bacterial culture or suspension。 aspects of biological agents like plague, cholera, and typhoid. Heinrich Himmler (1900-1945) seemed to be the only German leader to circumvent Hitler's orders, authorizing laboratories to carry out research into offensive bacteriological warfare and encouraging human experiments on concentration camp inmates.

Even taking into account the entirety of the German research activity into biological warfare, the German program was insignificant. No real organized cooperation was established with Axis powers. Nazi Germany never launched active research into biological warfare and never possessed bacteriological weapons ready to be used on the battlefield or for isolated actions. Hitler's own motives for prohibiting such offensive research remain unclear [5]. Botulinum toxin was not part of the German military arsenal during WW2.

\section{The Interrupted Work of the French Army}

French military research into bacteriological warfare was common in the years leading up to WW2. Most of the archives concerning French activities have been destroyed but some pertinent documents have been retrieved, allowing us to understand some aspects of this research [11].

In 1922, the French War Ministry created a bacteriology committee dealing with issues of bacteriological warfare. Émile Roux (1853-1933), director of the Institut Pasteur, and the bacteriologist Albert Calmette (18631933), who discovered the vaccine against tuberculosis, belonged to this committee. France signed the Geneva protocol in 1926 specifying that the treaty would not be applicable against countries that did not sign it. Shortly after, the bacteriology committee was renamed the prophylaxis committee. It was responsible for studying the potential weaponization of some bacteria, including $C$. botulinum. During this period, some researchers were victims of the toxin manipulation. One of them was André Pierre Marie (1891-1929), the son of the famous French neurologist Pierre Marie (1853-1940), who died in 1929 from botulism as he was working at the Institut Pasteur in Paris [12].

Officially, research was only conducted for defensive purposes. France, like many other countries, justified its offensive research by the need for retaliation in the event of an enemy bacteriological attack. Various structures were involved in the studies, such as the French Central Laboratory of the Naval Artillery, directed by Auguste Trillat (1861-1944), the French Center for the Study of Explosives located at Le Bouchet, and the Institut Pasteur. Trillat advocated the weaponization of botulinum toxin: "Although not yet proven experimentally, it appears that the botulinum toxin could take its place as an aggressive agent alongside other toxic products already in use" [11].

In 1937, the prophylaxis laboratory, directed by the military veterinarian Henri Velu (1887-1973), was organized at the Le Bouchet site and focused its work on ricin and botulinum toxin. In June 1938, as Nazi Germany had raised international tension to a high level, the prophylaxis committee heard the report of René Legroux (18771951) of the Institut Pasteur about the dispersal of botulinum toxin in air. Legroux prepared botulinum toxin for various experiments, showing that toxin activity was not changed by explosion.

During the Phony War, studies on botulinum toxin continued at Le Bouchet. In April 1940, Lord Victor Roth- 


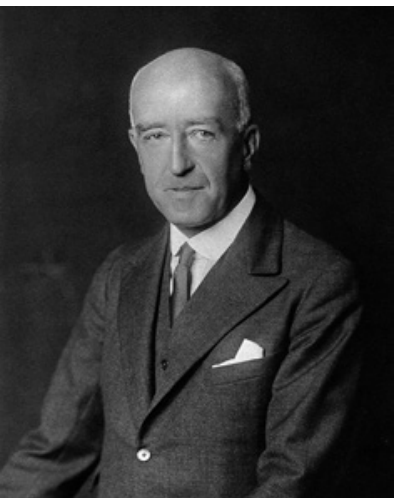

Fig. 4. Paul Fildes (1882-1971) (National Portrait Gallery, London).

schild (1910-1990), a biologist from the British Military Intelligence Section 5 (MI5) working closely with Porton Down teams, met Henri Velu in Paris. His report confirmed the French offensive experiments: "They are more advanced in the field of offensive experiments than we are and have obtained important results." British and French teams exchanged plans for shrapnel contaminated by bacteria [6] (shown in Fig. 3).

After the German invasion of the site of Le Bouchet in June 1940, it seems that the French secretly continued some of their studies during the occupation of France by German troops. At the Institut Pasteur, exchanges of scientific information, especially about plague and typhus vaccines, frequently took place [5]. René Legroux and Colette Jéramec (1896-1970) continued to work on botulism. Indeed, an increase in botulism cases was observed in France between 1940 and 1944 due to the poor quality of home-made canned food in a context of food shortage. Legroux is said to have boasted to the Germans that he had a jar of botulinum toxin capable of killing the entire German army ([13] p. 63).

\section{Porton Down and the British Studies}

After WW1, chemical warfare was a major concern in Great Britain, and from 1916 the British army had facilities for testing chemical weapons. They were located at Porton Down, near Salisbury (Wiltshire) in South of England. In 1930, Great Britain ratified the Geneva protocol with reservations and the military work on chemical agents continued at Porton Down.

In the 1930s, the discussions around Steed's documents acted as a trigger for the British government and a dedicated Bacteriological Warfare Subcommittee was created. At the outbreak of WW2, this subcommittee was integrated into a Biological Warfare Committee, under the chairmanship of Lord Maurice Hankey (1877-1963), in the British War Cabinet. Stimulated by the warnings of the Canadian physician Frederick Banting (1891-1941), Nobel laureate in 1923 as the co-discoverer of insulin, the issue of biological warfare came under consideration. Porton Down facilities were designated to host the main bacteriological warfare research projects. The microbiologist Paul Fildes (1882-1971) was appointed as a member of the new Biological Department at Porton Down in October 1940 and gradually became the most influential figure of the group [14] (shown in Fig. 4).

Botulinum toxin (code-named agent $\mathrm{X}$ ) was one of the main topics of the biological department alongside anthrax (agent N). Paul Fildes led thorough research into botulinum toxin. He established strong relationships with the Special Operations Executive as well as the US and Canadian scientists working on biological weapons. The development of the British program was deeply influenced by the unverified information from the intelligence services. On March 31, 1942, Paul Fildes himself insisted on some intelligence information on German botulinum toxin work: "Reports have been received from several sources... They have reference to the mass production of botulinum toxin in 'immense cement vats' situated in various stated localities in France and Germany. The toxin is finished as a powder of high potency. The names and addresses of the German experts engaged are given. There is nothing impossible in these reports; in fact the work is similar to that carried out at Porton, though on a greater scale" [15].

The results of botulinum toxin research at Porton Down were unconvincing. A simple method for mass production was still to be found; toxin batches varied considerably in toxicity. Most of the animal experiments were disappointing. The goal of sabotaging food to be used against soldiers or civilians was not achieved. The development of weapons utilizing the toxicity of botulinum toxin was proving impossible: "Coating the inside walls of bombs and shells with X, either dried on with adhesive or in liquid contact was ineffective. This was shown to be due to complete decomposition of the toxin by the heat developed in the shearing of the metal" [16]. The work of David Willis Henderson (1903-1968) did not support the view that botulinum toxin is likely to be an effective airborne weapon: the aerosols were highly labile. Botulism by inhalation seemed to be an unpredictable disease [17]. 


\section{The US Botulinum Toxin Research at Camp Detrick}

The USA signed the Geneva protocol in 1925 but did not ratify the treaty until 1975 . In the interwar period, the US army did not take an interest in the issue of biological warfare. This lack of interest in bacteriological weapons, including botulinum toxin, was confirmed in 1933 in a famous report by Major Leon Alexander Fox (1890-1965) [18].

During WW2, when alarmist information came from the intelligence services, the USA reconsidered its position. In April 1942, the Secretary of War Henry L. Stimson (1867-1950) recommended to President Franklin D. Roosevelt (1882-1945) the development of measures in the event of the need to use bacteriological weapons in retaliation. After long discussions, Roosevelt eventually approved the plan and created the War Reserve Service. The service was led by George W. Merck (1894-1957), a chemist and president of the pharmaceutical firm Merck and Co [19].

Secret research work began in numerous universities and in 1943 a large amount of funding was devoted to the construction of research facilities. The main center and pilot plant were located at Camp Detrick in Frederick (Maryland), a small National Guard airport (to be renamed Fort Detrick in 1956). The bacteriologist Ira Baldwin (1895-1999) became the director of the facility, in which a lot of young scientists served as military researchers. Among them was Edward Schantz (1908-2005) who was involved in the therapeutic development of botulinum toxin in the post-war years.

Botulinum toxin remained one of the main subjects of American biological warfare research. A lot of publications, staggered between 1946 and 1955, came from the work on botulinum toxin done at Camp Detrick during WW2 [20]. Research was focused on serotype A, the most common in the USA and the most pathogenic, but also because it was accepted that Germans and Japanese were working on type B. The potential German bacteriological threat was in reality unfounded, while the real Japanese threat seems to have been neglected by the US army.

The earliest goals of research were to isolate and purify the botulinum toxin [21]. Optimal culture media for the bacterium were developed, particularly for the Hall strain, chosen for its ability to produce abundant toxin and originally designed by Ivan C. Hall (1885-1975) a few years earlier. The seminal work of Hermann Sommer (1899-1950), a Swiss pharmacologist, and Tessmer Snipe formed the basis for the work on purification. They showed in the 1930s that the crude toxin can be precipitated from the culture broth with acid and a $\mathrm{pH}$ of 3.5 and extracted from the acid-treated precipitate by passing it through a suitable solution and then centrifuging $[2,3]$. The research work on purification of the toxin at Camp Detrick was carried out by 2 different groups led by Carl Lamanna (1916-1997) and Adolph Abrams (1919-2002).

The Abrams and Lamanna teams succeeded in obtaining a crystalline form of botulinum toxin shortly before the end of the war $[22,23]$. As a consequence, no weapon carrying this bacteriological agent was implemented before the end of the war.

From a chemical point of view, purification and crystallization of botulinum toxin is one of the major advances of Camp Detrick scientists. The "crystalline" form obtained was obviously not that of today's chemists, for whom this term means a highly purified protein suitable for 3-dimensional structure determination. The Camp Detrick preparations were far from pure, but the "crystalline" toxin they produced was an authentic neurotoxin with accompanying proteins that stabilize the toxin and prevent thermal and proteolytic degradation. Most of the insights derived from the work using this form of the toxin remain valid today.

\section{A Threat to Operation Overlord?}

The planning of Operation Overlord, the Allied invasion to liberate Europe, began in the spring of 1943. After discussion of many alternatives, it was decided that an initial assault force of 150,000 men would land on the beaches of Normandy, in northern France, in June 1944. The operation was led by the supreme commander of the Allied Expeditionary Force, American General Dwight D. Eisenhower (1890-1969).

Once more, intelligence service information was alarmist about the potential use of botulinum toxin by the Germans as a bacteriological weapon against the Allied troops, especially in a dry form. It was possible to evaluate this risk by assessing the immunization of German troops against various infectious diseases. To achieve this, blood samples were taken from German prisoners of war: "In the USA, the blood of 200 prisoners of war had already been examined with negative results and also of $40 \mathrm{Ger}-$ mans and Italians from North Africa where the results were again all negative" [24]. In spite of these negative results, the question of immunization of the Allied troops who would be involved in the Normandy landings was fiercely debated [25].

On May 22, 1944, the War Cabinet discussed the topic of botulism toxoid to immunize the Allied soldiers: "A
58

Eur Neurol 2021;84:53-60 DOI: $10.1159 / 000512812$
Tatu/Feugeas 
possible antidote 'Toxoid X' is not yet available in any quantity in this country, though it is under production in the USA and Canada. A demand has been placed on the Ministry of Supply by the war Office for sufficient toxoid to immunize 1.5 million men: the Americans are receiving supplies by air to build up stocks in this country" [25]. A toxoid, also called an anatoxin, is a toxin that has been treated so that its toxicity is destroyed but it retains its antigenicity, thereby inducing immunization. Toxoid made with formalin had been developed and tested in humans in the 1930s by the Russian physician Ivan Velikanov (1898-1938) [26]. Camp Detrick studies confirmed that formaldehyde was the most effective agent for detoxifying the botulinum toxin [21]. The toxoid production had begun in March 1943 with John Howard Mueller (1891-1954) and the Harvard group. Justified by the reports of intelligence services on Operation Overlord, an intensive production of anatoxin for serotype $\mathrm{A}$, then $\mathrm{B}$ and E, was launched at Camp Detrick.

Finally, new British intelligence reports provided irrefutable evidence that the Germans did not have the capability to launch an effective botulinum toxin attack against Operation Overlord. British and American leaders abandoned plans to inoculate the soldiers. Washington was informed of this decision: "British and American opinion in this country is however that as Toxin $\mathrm{X}$ is only part of bacteriological threat, and is discounted by best authorities here, it is not worth inoculating troops now, and in any case time factor prevents action before Overlord" [25].

The Canadian staff was reluctant to abandon the immunization of their troops with their stocks of toxoid: "but having learnt the Supreme Headquarters Allied Expeditionary Force and War Office feeling have referred the matter again to Canada." Ottawa was forced to relent $[25,27]$.

The Canadian troops who landed on the Normandy beaches on June 6,1944 , were not inoculated, nor were the British and American soldiers. The assault troops went in wearing protective clothing and carrying their gas masks ready for a chemical attack, but not for a biological one. They did not encounter botulinum toxin weapons. Botulinum toxoid development is one of the most lasting legacies of the WW2 botulinum toxin biowarfare research.

\section{WW2 Botulinum Toxin Myths and Anecdotes}

Overall, there is no documentary evidence that weaponized botulinum toxin was used either by Germany or by the Allies on the European battlefield. Nevertheless, some legends about its use by special agents or partisans are still alive.

The botulinum toxin attack against the high-ranking German Nazi Reinhard Heydrich (1904-1942) during Operation Anthropoid in May 1942 in Prague is one popular example of such myths. Using the now declassified British archives from Operation Anthropoid and of the chemical and bacteriological warfare centers as well as medical reports, it has been proved that this hypothesis was unrealistic [28]. This legend was spread in the 1970s by Julian Perry Robinson who recognized in 2016 that his statement that weaponized botulinum toxin was sent from Camp Detrick to Special Operations Executive during the planning of the assassination of Heydrich was not based on a reliable account. The main agent in the spread of this legend was the British microbiologist Paul Fildes, who led research into toxins at Porton Down, where he was controversial because of his meddling in extra-medical problems. His various belated testimonies are tainted by his known tendencies for boasting and exaggeration [28].

Some other anecdotes involving weaponized botulinum toxin are difficult to authenticate. It has been reported that the US Office of Strategic Services developed a plan for Chinese prostitutes to assassinate high-ranking officers in contact with them in occupied Chinese cities. The chemist Stanley P. Lovell (1890-1976) prepared very small gelatin capsules containing a lethal dose of botulinum toxin to slip into Japanese officers' food and drink. The normal background of botulism cases was supposed to deflect suspicion from the prostitutes. After the delivery of the capsules to China, the American Navy detachment tested the capsules on donkeys, who lived after the test. Lovell was informed and the project was abandoned. He stated later that donkeys were one of the few living creatures immune to botulism [29] ([30] p. 86-88).

Another example is reported in Germany. In April 1941, Walter Schellenberg (1910-1952), one of Hitler's Intelligence chiefs, was asked to plan the assassination of Otto Strasser (1897-1974). Strasser was suspected of organizing an attack against Hitler and had just been located in Portugal. In order to prepare this operation, Schellenberg, Himmler, and Heydrich met Horst Strassburger (1909-1944), a physician and expert in bacteriology from the Munich Hygiene Institute, who was called by Himmler to Berlin to work on bacteriological warfare ([31] p. 41-42). Strassburger had brought with him 2 flasks containing a highly lethal bacterial fluid that Schellenberg carefully took with him to Lisbon. The flasks contained a "deadly, rapid acting bacterial preparation suf- 
ficient to intoxicate the water supply of a city with a million inhabitants" ([32] p. 258). According to Geissler, the flasks presumably contained botulinum toxin: no other substance has these characteristics and Strassburger was heavily involved in research into this toxin [33]. Finally, Strasser never appeared to Schellenberg in Portugal and the operation was canceled ([31] p. 41-42).

\section{Conclusion}

The failures to weaponize botulinum toxin during WW2 were the first demonstration that this toxin is not a useful bacteriological warfare agent. Nevertheless, major progress (purification, toxoid) arose from the military research. The main consequence is that all these studies, although ineffective for weaponization, provided useful data for the first steps of the therapeutic use of botulinum toxin in the following years.

\section{Acknowledgement}

The authors thank Jennifer Dobson for proofreading the manuscript and translation of original quotations.

\section{Conflict of Interest Statement}

The authors have no conflicts of interest to declare.

\section{Funding Sources}

This research did not receive any specific grant from funding agencies in the public, commercial, or not-for-profit sectors.

\section{Author Contributions}

Laurent Tatu was in charge of writing the article and Jean-Paul Feugas performed the critical review of the manuscript.

\section{References}

1 van Ermengem E. Ueber einen neuen anaëroben Bacillus und seine Beziehungen zum Botulismus. Z Hyg Infekt. 1897;26(1):1-56.

2 Snipe PT, Sommer H. Studies on botulinus toxin. 3. Acid precipitation of botulinus toxin. J Infect Dis. 1928;43(2):152-60.

3 Sommer H. Purification of botulinus toxin. Exp Biol Med. 1937;35(4):520-1.

4 Hugh-Jones M. Wickham steed and German biological warfare research. Intell Natl Secur. 1992;7(4):379-402.

5 Geissler E. Biological warfare activities in Germany, 1923-45. In. Biological and toxin weapons: research, development, and use from the Middle Ages to 1945. Oxford; New York: Oxford University Press; 1999.

6 British National Archives (Kew). WO 188/653.

7 Dulles A, Petersen NH. Mazal Holocaust Collection, United States, Office of Strategic Services, Bern Office. From Hitler's doorstep: the wartime intelligence reports of Allen Dulles, 1942-1945. University Park: Pennsylvania State University Press; 1996.

8 British National Archives (Kew). WO $188 / 654$.

9 British National Archives (Kew). CAB 81/155.

10 Hart JD. The ALSOS Mission, 1943-1945: a Secret U.S. Scientific Intelligence Unit. Int J Intell Counterintelligence. 2005;18(3):50837.
11 Lepick O. French activities related to biological warfare, 1919-1945. In. Biological and toxin weapons: research, development, and use from the Middle Ages to 1945. Oxford; New York: Oxford University Press; 1999.

12 Béhague P. André Pierre-Marie (1891-1929). Presse Médicale. 1929:1017-8.

13 Perrot A, Schwartz M. Le génie de Pasteur au secours des poilus. Paris, France: Odile Jacob; 2016. p. 282.

14 Carter GB, Pearson GS. British biological warfare and biological defence, 1925-1945. In. Biological and toxin weapons: research, development, and use from the middle ages to 1945. Oxford; New York: Oxford University Press; 1999.

15 British National Archives (Kew). WO 188/656.

16 British National Archives (Kew). WO 188/701.

17 British National Archives (Kew). BDP 37.

18 Fox LA. Bacterial warfare: the use of biologic agents in warfare. Mil Surg. 1933;72:189207.

19 Bernstein BJ. America's biological warfare program in the Second World War. J Strateg Stud. 1988;11(3):292-317.

20 Lebeda FJ, Adler M, Dembek ZF. Yesterday and today: the impact of research conducted at camp Detrick on Botulinum Toxin. Mil Med. 2018;183(5-6):85-95.

21 Cochrane RC. History of the chemical warfare service in WW2. Biological warfare research in the United States. Historical section. Office of Chief Chemical Corps; 1947.
22 Lamanna C, Eklund HW, McElroy OE. Botulinum toxin (type A); including a study of shaking with chloroform as a step in the isolation procedure. J Bacteriol. 1946 July;52:1-13.

23 Abrams A, Kegeles G, Hottle GA. The purification of toxin from Clostridium botulinum type A. J Biol Chem. 1946 July;164:63-79.

24 British National Archives (Kew). CAB 81/55.

25 British National Archives (Kew). CAB 121/103.

26 Velikanov Ivan M. Experimental immunization of man against botulism. Klin Med. 1934; 12:1802-6.

27 Avery D. Canadian biological and toxin warfare research, development and planning, 1925-1945. In. Biological and toxin weapons: research, development, and use from the Middle Ages to 1945. Oxford; New York: Oxford University Press; 1999.

28 Tatu L, Jost W, Bogousslavsky J. The botulinum toxin legend of Reinhard Heydrich's death: the end of "Himmler's brain". Neurology. 2017;89(1):84.

29 Sotos JG. Botulinum toxin in biowarfare. JAMA. 2001;285(21):2716.

30 Lovell, Stanley P. Of spies \& stratagems. Englewood Cliffs: Prentice-Hall; 1963.

31 Doerries RR, Weinberg GL. Hitler's intelligence chief: Walter Schellenberg. 1st ed. New York: Enigma Books; 2009.

32 Walter S. Aufzeichnungen. Die memorien des letzeten Geheimsdienst unter Hitler. Limes: Wiesbaden; 1979.

33 Geissler E. More about the Heydrich assassination. ASA Newsl. 1996;6:10. 